The International Journal of Banking and Finance, Volume 9 (Number 2) 2012: pages 77-88

\title{
BANKING COMPETITION AND EFFICIENCY IN JORDAN: A NOTE
}

\author{
Khaldoun Al-Qaisi
}

Amman Arab University, Jordan

\begin{abstract}
The financial economics literature contains numerous research papers which examine issues that concern the banking industry. One of these issues is banking competition. Indeed, this issue is important because of its implications to financial stability and the growth of the borrowing firms. The purpose of this paper is to assess the competitive behavior of the Jordanian banking sector during the period ranging from 1999 to 2008 using the nonstructural test developed by Panzar and Rosse. In more specific terms, this paper examines the overall competitive condition during the period 1999 - 2008 and how it has evolved over time. Based on the empirical findings, it is expected that a number of policy recommendations may be provided. The objective of these recommendations is to enhance the regulation of the banking sector in Jordan and improve their performance.
\end{abstract}

Key Words: Financial economics, Banking competition, Jordanian banking sector, Financial stability, Economic growth

JEL Classification: G21, G32, E44, E51

\section{Introduction}

It is common knowledge that the theoretical predictions of the financial development and economic growth nexus are well supported by many cross-country, industry-level, and firmlevel research papers. Based on this vast literature, one can state that the role of finance in economic growth has become a stylized fact. Indeed the literature has shifted its attention to other and related issues such as the determinants of financial development and the development of new measures of financial development and economic growth.

The issue of financial development is relatively important for study in the Jordanian case. This is based on a number of observations. First, all Jordanian banks are private and listed on the local stock exchange (Amman Securities Exchange). Second, the total number of bank branches has increased from 25 in 1970 to 438 by 2008. Third, the ratio of total bank 
assets to GDP is equal to 33.4 per cent in 1970 . This ratio has improved to 209 per cent by the end of 2008. Finally, the ratio of bank credit to the private sector as per cent of GDP has increased from 19.9 per cent to 93 per cent over the same period.

The fact is that financial intermediaries are economically important and finance literature contains a large number of papers examining an equally large number of banking issues. These include, for example, the determinants of net interest margin, determinants of bank capital, impact of foreign bank entry on the performance of local banks, and bank competition.

Against this background, the primary objective of this research is to provide answers to the following questions: (i) What is the degree of competition within the Jordanian banking industry during the period 2000-2008?; and (ii) Has there been a shift in the intensity of competition within the Jordanian banking industry?

The rest of the paper is organized as follows. After a brief description in the next section about the growth in size and intensity of banking sector over a 50-year history, we provide in section 3 the data description and the methodology. The results are also discussed in the same section. Conclusions are drawn in section 4.

\section{The Jordanian Banking Sector}

The banking system in Jordan consists of the Central Bank of Jordan (CBJ), licensed banks, and specialized credit institutions. The establishment of licensed banks in Jordan dates back to 1925 when the Ottoman Bank (later to become British Bank) started its operations. Following this, and due to the 1948 Arab-Israeli War, the Arab Bank, which was established in Palestine (Jerusalem) in 1930, moved its headquarters to Amman (Jordan). In other words, since the late 1950s and early 1960s, the Jordanian economy has been witnessing the growth of privately licensed banks. Indeed, since that time period, the total number of banks has grown to reach thirteen national banks, two Islamic banks, and eight foreign banks.

In Table 1, we report data on some basic information to reflect the development of the Jordanian banking sector. Based on the reported figures, we can make the following observations. First, the size of Jordanian banks is extremely large. For example, the ratio of the total assets of all Jordanian banks has increased from 33.4 per cent (1970) and 91.9 per 
cent (1980) to more than 200 per cent by the end of 2002. Since then, this ratio has been consistently above the 200 per cent mark.

Second, it is interesting to note that Jordanian banks hold high proportions of their assets in the form of foreign assets and these are largely deposits in foreign banks operating outside Jordan. Indeed, by the end of 2008, this proportion has reached 19.5 per cent. Finally, it is useful to note that the available figures indicate that during the period Jordanian banks accounted for about 90 per cent of the assets, deposits, and credit of all licensed commercial banks in the country. In other words, non-Jordanian banks are relatively small and, as mentioned above, geographically concentrated in a limited number of cities (mostly in the capital).

Table 1: Assets of Jordanian Banks, 1964 - 2008

\begin{tabular}{|c|c|c|c|c|}
\hline Year & $\begin{array}{c}\text { Total Assets } \\
\text { (Million JD) }\end{array}$ & $\begin{array}{c}\text { Total Assets / } \\
\text { GDP }\end{array}$ & $\begin{array}{c}\text { Foreign Assets } \\
\text { (Million JD) }\end{array}$ & $\begin{array}{c}\text { Foreign Assets } \\
\text { / Total Assets }\end{array}$ \\
\hline 1970 & 76.4 & 0.334 & 6.1 & 0.080 \\
\hline 1980 & 1070.5 & 0.919 & 205.2 & 0.192 \\
\hline 1990 & 4090.0 & 1.481 & 1045.7 & 0.256 \\
\hline 2000 & 12913.5 & 2.153 & 3711.7 & 0.287 \\
\hline 2002 & 15119.3 & 2.225 & 4492.7 & 0.297 \\
\hline 2004 & 17821.1 & 2.203 & 5002.1 & 0.281 \\
\hline 2006 & 24237.6 & 2.304 & 6203.4 & 0.256 \\
\hline 2007 & 26815.6 & 2.288 & 6516.5 & 0.243 \\
\hline 2008 & 29796.6 & 2.100 & 5810.3 & 0.195 \\
\hline
\end{tabular}

Source: Various Central Banks of Jordan Annual Reports.

Table 2: Deposits and Credit

\begin{tabular}{|c|c|c|c|}
\hline Year & Deposits / GDP & $\begin{array}{c}\text { Private Sector } \\
\text { Deposits / GDP }\end{array}$ & $\begin{array}{c}\text { Credit to Private } \\
\text { Sector / GDP }\end{array}$ \\
\hline 1970 & 0.253 & 0.201 & 0.199 \\
\hline 1980 & 0.694 & 0.613 & 0.484 \\
\hline 1990 & 0.957 & 0.849 & 0.675 \\
\hline 2000 & 1.373 & 1.135 & 0.759 \\
\hline 2002 & 1.379 & 1.192 & 0.755 \\
\hline 2004 & 1.429 & 1.268 & 0.765 \\
\hline 2006 & 1.387 & 1.266 & 0.928 \\
\hline 2007 & 1.364 & 1.245 & 0.964 \\
\hline 2008 & 1.276 & 1.156 & 0.930 \\
\hline
\end{tabular}

Source: Various Central Bank of Jordan Annual Reports. 
On the liabilities side, it is noticeable that all licensed banks have growth in importance relative to the size of the national economy. For example, we can see in Table 2 that the ratio of total deposits to GDP (total private sector deposits to GDP) has increased from about 96 per cent in1990 to reach 127.6 per cent by the end of 2008. Similarly, the ratio of total credit provided by all licensed banks to the private sector has also increased significantly to reach 93 per cent of GDP as at 2008. As expected, a large proportion of the credit which is provided to the private sector is made in the local currency. As reported in Table 3, less than 5 per cent of the credit provided to the private sector is denominated in foreign currencies. Indeed, this is expected due to the higher risk involved in lending in foreign currencies.

Table 3: Proportion of Credit to Private Sector in Foreign Currency to Total Credit

\begin{tabular}{|c|c|}
\hline Year & Proportion \\
\hline 2000 & 0.048 \\
\hline 2002 & 0.051 \\
\hline 2003 & 0.055 \\
\hline 2004 & 0.041 \\
\hline 2005 & 0.029 \\
\hline 2006 & 0.032 \\
\hline 2007 & 0.027 \\
\hline 2008 & 0.041 \\
\hline
\end{tabular}

Source: Various Central Banks of Jordan Annual Reports.

Table 4: The Distribution of Total Credit

\begin{tabular}{|l|c|c|c|c|c|c|c|}
\hline \multicolumn{1}{|c|}{ Sector } & $\mathbf{2 0 0 0}$ & $\mathbf{2 0 0 2}$ & $\mathbf{2 0 0 4}$ & $\mathbf{2 0 0 5}$ & $\mathbf{2 0 0 6}$ & $\mathbf{2 0 0 7}$ & $\mathbf{2 0 0 8}$ \\
\hline Agriculture & 0.028 & 0.020 & 0.018 & 0.014 & 0.014 & 0.014 & 0.016 \\
\hline Mining & 0.022 & 0.018 & 0.013 & 0.007 & 0.004 & 0.006 & 0.004 \\
\hline Industry & 0.150 & 0.154 & 0.145 & 0.127 & 0.112 & 0.119 & 0.121 \\
\hline Commerce & 0.244 & 0.244 & 0.238 & 0.205 & 0.196 & 0.216 & 0.221 \\
\hline Construction & 0.164 & 0.149 & 0.154 & 0.150 & 0.160 & 0.172 & 0.172 \\
\hline Transport & 0.029 & 0.032 & 0.028 & 0.028 & 0.030 & 0.031 & 0.027 \\
\hline Tourism & 0.034 & 0.034 & 0.025 & 0.023 & 0.020 & 0.023 & 0.028 \\
\hline Services & 0.053 & 0.068 & 0.080 & 0.072 & 0.065 & 0.065 & 0.064 \\
\hline Financial & 0.034 & 0.027 & 0.016 & 0.023 & 0.025 & 0.034 & 0.032 \\
\hline Individuals & 0.241 & 0.253 & 0.284 & 0.351 & 0.373 & 0.320 & 0.316 \\
\hline Total & 1.00 & 1.00 & 1.00 & 1.00 & 1.00 & 1.00 & 1.00 \\
\hline
\end{tabular}

Source: Various Central Bank of Jordan Annual Reports.

In addition to the above, statistics in Table 4 provide information on the distribution of the credit provided by licensed banks to the various sectors of the economy. Again, based on these figures, one can observe a number of interesting points. For example, the agricultural 
sector accounts for a very small proportion of the total credit (1.4 per cent). This observation is not surprising if one realizes that the agriculture sector accounts for a small proportion of the national economy (about 2 per cent of GDP). In contrast to the agricultural sector, it is interesting to note that the largest proportion of the credit goes to private individuals (31.6 per cent). These are mostly short term bank credit and overdraft facilities.

\section{Literature Review on Bank Competition}

In the literature, there are three approaches to empirically evaluate the degree of competition in, thus the efficiency of the banking industry. These are: Panzar and Rosse (1982 and 1987), Lau (1982, and Hall (1988). However, the H-statistic approach of Panzar and Rosse is the most popular non-structural model which has been used by many researchers to examine the competitive structure of the banking industry in various countries.

The Panzar-Rosse methodology develops a test statistic (named H-statistic) to distinguish between oligopolistic, competitive, and monopolistic markets. The H-statistic is computed from the reduced-form revenue equation at the bank level and this can serve as a measure of the competitive behaviour of banks under certain assumptions. These assumptions include (i) profit maximization at bank and industry levels, (ii) equilibrium in the industry, and (iii) conventional cost and demand structures.

Market power is evaluated by the extent to which changes in factor prices are reflected in the equilibrium revenues. The sum of the elasticities of the reduced-form revenues with respect to input prices defines the competitive indicator (the H-statistic). The magnitudes of the estimated values of the $\mathrm{H}$-statistic indicate the market structure of the industry and a summary. If the market structure is characterized by monopolistic competition, the H-statistic lies between zero and one, as revenues increase less than proportionately to changes in input prices. If the market is characterized by perfect competition, the H-statistic is equal to one. Indeed, any increase in input prices will increase both marginal and average costs without changing the equilibrium output of any individual bank. This is the case because any bank which cannot cover the increase in its input prices will be forced out of the market.

An important feature of the H-statistic is that it must be performed on banks which are in long-run equilibrium. This can be tested by regressing the return on asset (ROA) instead of bank revenue on input prices. If the sum of the elasticities is equal to zero, this indicates long- 
run equilibrium (E-statistic). If the sum of the elasticities is negative, this indicates disequilibrium (E-statistic).

The Panzar-Rosse approach has been widely used in the literature, so a study of Jordanian banks using this method should provide reliable comparisons. Indeed, the number of papers applying this method is very large and we review only a few. However, some of the main papers, which examined competition in the emerging country banks are examined by Yildrim and Philippatos (2007), Prasad and Ghosh (2005). t is reported (Turk-Ariss, 2009) that banks in the Middle East and North Africa (MENA) region operate under conditions of monopolistic competition. This result is also supported by a much earlier paper by Murjan and Ruza (2002).

\section{Data, Methodology and results}

To assess the competitive behaviour of the Jordanian banking sector during the period 2000 to 2008, a total of 12 listed Jordanian banks are analysed. Based on the international evidence, the following two models are estimated to arrive at the measures of competitiveness in the Jordanian banking industry:

$$
\begin{aligned}
& \operatorname{lnREV} \text { it }=\alpha_{0}+\alpha_{1} \operatorname{lnPE}_{\mathrm{it}}+\alpha_{2} \operatorname{lnIE}_{\mathrm{it}}+\alpha_{3} \operatorname{lnOOE}_{\mathrm{it}}+\alpha_{4} \operatorname{lnCAP} \mathrm{it}_{\mathrm{it}}+\alpha_{5} \operatorname{lnSIZEit} \\
& +\alpha_{6} \operatorname{lnRISK}_{\mathrm{it}}+\alpha_{7} \operatorname{lnGRO}_{\mathrm{t}}+\varepsilon_{\mathrm{it}} \\
& \operatorname{lnINTREV}_{\mathrm{it}}=\alpha_{0}+\alpha_{1} \operatorname{lnPE} \mathrm{E}_{\mathrm{it}}+\alpha_{2} \operatorname{lnIE}_{\mathrm{it}}+\alpha_{3} \operatorname{lnOOE}_{\mathrm{it}}+\alpha_{4} \operatorname{lnCAP}_{\mathrm{it}}+\alpha_{5} \operatorname{lnSIZEit} \\
& +\alpha_{6} \operatorname{lnRISK}_{\mathrm{it}}+\alpha_{7} \operatorname{lnGRO}_{\mathrm{t}}+\varepsilon_{\mathrm{i}}
\end{aligned}
$$

where ln stands for the natural logarithm, REV is the ratio of bank revenue (interest and noninterest) to total assets, INTREV is the ratio of interest revenue to total assets, PE is the ratio of personnel expenses to total assets, IE is the ratio of interest expenses to total deposits, OOE is the ratio of other operating expenses to total assets, CAP is the ratio of equity capital to total assets, SIZE is total assets, RISK is net loans to total assets, and GRO is the real GDP growth rate. 
The subscripts $\mathrm{i}$ and $\mathrm{t}$ denote banks $(\mathrm{i}=1, \ldots, \mathrm{N})$ and time $(\mathrm{t}=1, \ldots, \mathrm{T})$ respectively. In expression (1), the dependent variable (REV) is used to measure market competitiveness with respect to the overall banking activities. In expression (2), the dependent variable (INTREV) is used to focus on the core banking activity (lending).

Based on the above two expressions, the H-statistic is given by $\mathrm{H}=\alpha_{1}+\alpha_{2}+\alpha_{3}$. In other words, the sum of these three coefficients indicates how bank total revenues (REV) or interest revenues (INTREV) react to changes in the three input prices (PE, IE, and OOE). As far as the other independent variables are concerned, they account for bank-specific (CAP and RISK) and market-specific (GROWTH) variables.

In addition, and as mentioned above, the equilibrium condition is modelled as follows:

$$
\begin{aligned}
& \operatorname{lnROA} A_{i t}=\alpha_{0}+\alpha_{1} \ln \mathrm{PE}_{\mathrm{it}}+\alpha_{2} \operatorname{lnIE}_{\mathrm{it}}+\alpha_{3} \operatorname{lnOOE}_{\mathrm{it}}+\alpha_{4 \ln } \mathrm{CAP}_{\mathrm{it}} \\
& +\alpha_{5 \ln } \text { SIZEit }+\alpha_{6 l n} \text { RISK }_{\text {it }}+\alpha_{7} \operatorname{lnGRO}_{\mathrm{t}}+\varepsilon_{\text {it }}
\end{aligned}
$$

Where ROA is the pre-tax return on assets and the independent variables are as defined above. The market is in long-run equilibrium if $E=\alpha_{1}+\alpha_{2}+\alpha_{3}=0$. In other words, bank's rates of return should not be significantly correlated with input prices. A constant is added to ROA to avoid the natural logarithm of a negative number.

\section{Table 5: Descriptive Statistics}

REV is the ratio of bank revenue (interest and non-interest) to total assets, INTREV is ratio of interest revenue to total assets, ROA is return on assets, $\mathrm{PE}$ is ratio of personnel expenses to total assets, IE is ratio of interest expenses to total deposits, OOE is the ratio of other operating expenses to total assets.

\begin{tabular}{|l|c|c|c|c|}
\hline \multicolumn{1}{|c|}{ Measure } & Mean & Median & Minimum & Maximum \\
\hline REV & 0.071 & 0.071 & 0.030 & 0.103 \\
\hline INTREV & 0.054 & 0.055 & 0.029 & 0.083 \\
\hline ROA & 0.018 & 0.018 & -0.041 & 0.061 \\
\hline PE & 0.011 & 0.010 & 0.003 & 0.029 \\
\hline IE & 0.015 & 0.014 & 0.003 & 0.046 \\
\hline OOE & 0.026 & 0.025 & 0.006 & 0.075 \\
\hline
\end{tabular}

To assess the competitive behaviour of the sector, the estimations are carried out for a balanced panel of banks over the period 2000-08. In addition, the sample period is divided 
into two sub-periods: these are 2000-04 and 2004-08. This analysis should enable us to conclude whether there has been any change in the competitive conditions in the Jordanian banking sector. Finally, to estimate the regressions $1-3$, the method that we use is Period Seemingly Unrelated Regression (SUR) - Pooled Estimated Generalized Least Squares (EGLS).

In Table 5, we report the summary data for the dependent and cost variables which are used in the empirical analysis. As one might expect, the reported statistics reflect the presence of some variations between the 12 banks and this can be seen from the reported minimum and maximum values. Note that the ROA is pretty much comparable to the statistics across international studies. In Tables 6, 7, and 8, we present the estimation from models (1), (2), and (3). In addition, we report in Table 8 the sum of the three coefficients (personnel expenses, interest expenses, and other operating expenses) to judge the efficiency levels.

\section{Table 6: Model 1 Estimation Results}

$\operatorname{lnREV} V_{\text {it }}=\alpha_{0}+\alpha_{1} \operatorname{lnPE} E_{\text {it }}+\alpha_{2} \operatorname{lnIE}_{\text {it }}+\alpha_{3} \operatorname{lnOOE}_{\text {it }}+\alpha_{4} \operatorname{lnCAP} \operatorname{Pit}+\alpha_{5} \ln$ SIZEit $+\alpha_{6} \operatorname{lnRISK}$ it + $\alpha_{7} \operatorname{lnGRO}_{\mathrm{t}}+\varepsilon_{\mathrm{it}} . \ln$ is natural logarithm, REV is the ratio of bank revenue (interest and noninterest) to total assets, PE is ratio of personnel expenses to total assets, IE is ratio of interest expenses to total deposits, OOE is ratio of other operating expenses to total assets, CAP is ratio of equity capital to total assets, SIZE is total assets, RISK is net loans to total assets, and GROWTH is real GDP growth rate.

\begin{tabular}{|c|c|c|}
\hline Variable & Coefficient & t-Statistic \\
\hline $\ln P E$ & -0.057 & -0.637 \\
\hline $\operatorname{lnIE}$ & 0.220 & $2.499^{*}$ \\
\hline $\operatorname{lnOOE}$ & 0.001 & 0.043 \\
\hline $\operatorname{lnCAP}$ & -0.025 & -1.227 \\
\hline $\operatorname{lnSIZE}$ & -0.086 & $-10.404^{*}$ \\
\hline lnRISK & 0.039 & $3.516^{*}$ \\
\hline $\operatorname{lnGRO}$ & -0.131 & $-2.078^{* *}$ \\
\hline Adjusted $\mathrm{R}^{2}$ & \multirow{3}{*}{\multicolumn{2}{|c|}{$\begin{array}{c}0.897 \\
1.870 \\
744^{*}\end{array}$}} \\
\hline Durbin-Watson Sts. & & \\
\hline F-Statistic & & \\
\hline
\end{tabular}

As is evident from the statistics in Model (1) results in Table 6, the model fit is well established with high adjusted R-square values and F-ratio. The same could be said of the results in Table 7 for Model (2) and in Table 8 for Model (3).

The estimation of the three critical parameters in the three sets of results suggest that the Jordanian banking sector is not competitive since the summed coefficients fall short for 
that conclusion to be made. The statistics suggest that the banking sector is monopolistic competition, which is indicative of its relative inefficiency.

\section{Table 7: Model 2 Estimation Results}

$\operatorname{lnINTREV}$ it $=\alpha_{0}+\alpha_{1} \operatorname{lnPE}_{\text {it }}+\alpha_{2} \operatorname{lnIE}_{\text {it }}+\alpha_{3} \operatorname{lnOOE}_{\text {it }}+\alpha_{4} \operatorname{lnCAP}_{\text {it }}+\alpha_{5} \operatorname{lnSIZEit}+\alpha_{6} \operatorname{lnRISK}_{\text {it }}+$ $\alpha_{7} \operatorname{lnGRO}_{\mathrm{t}}+\varepsilon_{\mathrm{it}}$. ln is natural logarithm, INTREV is ratio of interest revenue to total assets, PE is ratio of personnel expenses to total assets, IE is ratio of interest expenses to total deposits, OOE is ratio of other operating expenses to total assets, CAP is ratio of equity capital to total assets, SIZE is total assets, RISK is net loans to total assets, and GROWTH is real GDP growth rate.

\begin{tabular}{|c|c|c|}
\hline Variable & Coefficient & t-Statistic \\
\hline $\operatorname{lnPE}$ & -0.192 & $-2.627^{*}$ \\
\hline $\operatorname{lnIE}$ & 0.371 & $4.799^{*}$ \\
\hline $\operatorname{lnOOE}$ & -0.042 & $-2.566^{*}$ \\
\hline $\operatorname{lnCAP}$ & -0.026 & $-1.946^{* * *}$ \\
\hline $\operatorname{lnSIZE}$ & -0.075 & $-18.040^{*}$ \\
\hline $\operatorname{lnRISK}$ & 0.079 & $9.733^{*}$ \\
\hline $\operatorname{lnGRO}$ & -0.467 & $-21.769^{*}$ \\
\hline Adjusted $\mathrm{R}^{2}$ & \multirow{3}{*}{\multicolumn{2}{|c|}{$\begin{array}{c}0.898 \\
1.907 \\
555^{*}\end{array}$}} \\
\hline Durbin-Watson Sts. & & \\
\hline F-Statistic & & \\
\hline
\end{tabular}

Table 8: Model 3 Estimation Results

$\operatorname{lnROA} A_{i t}=\alpha_{0}+\alpha_{1} \operatorname{lnPE}_{\mathrm{it}}+\alpha_{2} \operatorname{lnIE}_{\mathrm{it}}+\alpha_{3} \operatorname{lnOOE}_{\mathrm{it}}+\alpha_{4} \operatorname{lnCAP}_{\mathrm{it}}+\alpha_{5} \operatorname{lnSIZEit}+\alpha_{6} \operatorname{lnRISK}_{\mathrm{it}}+$ $\alpha_{7} \operatorname{lnGRO}_{t}+\varepsilon_{i t}$. ln is natural logarithm, REV is the ratio of bank revenue (interest and noninterest) to total assets, INTREV is ratio of interest revenue to total assets, PE is ratio of personnel expenses to total assets, IE is ratio of interest expenses to total deposits, OOE is ratio of other operating expenses to total assets, CAP is ratio of equity capital to total assets, SIZE is total assets, RISK is net loans to total assets, and GROWTH is real GDP growth rate.

\begin{tabular}{|c|c|c|}
\hline Variable & Coefficient & t-Statistic \\
\hline $\operatorname{lnPE}$ & -0.011 & -1.464 \\
\hline $\operatorname{lnIE}$ & 0.023 & $2.984^{*}$ \\
\hline $\operatorname{lnOOE}$ & -0.022 & $-9.544^{*}$ \\
\hline $\operatorname{lnCAP}$ & 0.001 & 0.499 \\
\hline $\operatorname{lnSIZE}$ & -0.001 & $-2.689^{*}$ \\
\hline $\operatorname{lnRISK}$ & 0.001 & 1.332 \\
\hline InGRO & 0.009 & $3.010^{*}$ \\
\hline Adjusted R & & 0.863 \\
\cline { 1 - 1 } Durbin-Watson St & & 1.927 \\
\cline { 1 - 3 } F-Statistic & & $113^{*}$ \\
\cline { 1 - 3 } & &
\end{tabular}


The Panzar-Rosse statistics are obtained from the three regressions for the whole period and for two sub-periods of the study. These are summarized in Table 9. It is evident from these statistics that the desired competition level is not yet achieved despite the banks being operated by private sector and fast phased development over the test period, in fact impressive gains in size variables.

Table 9: Panzar-Rosse Statistics

REV is the ratio of bank revenue (interest and non-interest) to total assets, INTREV is ratio of interest revenue to total assets, ROA is return on assets

\begin{tabular}{|l|c|c|c|}
\hline & $\mathbf{2 0 0 0 - 2 0 0 8}$ & $\mathbf{2 0 0 0 - 2 0 0 4}$ & $\mathbf{2 0 0 4 - 2 0 0 8}$ \\
\hline REV & 0.164 & 0.277 & 0.082 \\
\hline INTREV & 0.137 & 0.009 & 0.070 \\
\hline ROA & -0.010 & -0.016 & -0.006 \\
\hline
\end{tabular}

In summary then an international comparison would place Jordanian banks as being monopolistic rather than fully competitive as are such developing economies as Malaysia and Korea. The banking sector has to develop to be at least oligopolistic before becoming competitive. For that pointed reforms are needed in the management of the banks in Jordan.

\section{Summary and Conclusions}

The issue of financial development cannot be overstressed in Jordan. Indeed, this is based on many factors including the fact that while economic growth averaged 7.4 per cent a year in real terms during the 2004-08 test period, the national economy could not reduce its unemployment rate, which is around 12 to 14 per cent. It is higher for the young people (20 to 24 years): it is equal to 27 per cent. This is why successive governments have persevered with some consistent policies including the commitment to the promotion of the role of the private sector.

This policy (private sector promotion) makes the private sector, at once a major player, an instrumental actor, and a direct beneficiary of any expected economic gains. Indeed, we can state that the banking system in Jordan constitutes a major part of this private sector. This is based on a number of observations. First, all Jordanian banks are private and listed on the local stock exchange. Second, the total number of banks has increased and third, 
the ratio of total bank assets to GDP has also increased. Finally, the ratio of bank credit to the private sector has increased as well.

The fact that the economy faces a number of economic challenges, the Jordanian banking system is relatively expanded, financial intermediaries in general are economically important. The costs of any bank failure are much greater than that of other businesses. Has the banks, while growing larger, how do they fare in terms of competition to provide the welfare maximization to the economy and the people?

The empirical results show that the Jordanian banking system operates under monopolistic competitive conditions, and has to move towards more efficient status to provide welfare maximization. In addition, it is concluded that the time period 2000-2008 has not witnessed any change in this condition.

The implications of this finding are straight forward. Jordanian policy-makers must realize the status of competitiveness in the banking sector so that its competitive efficiency has to be increased. That should be the major focus for the period ahead. Indeed, this is probably why during the past few years, a total of six Arab and foreign banks have been allowed to operate, to increase competition. In other words, it would be interesting to examine the impact of foreign bank entry on the competitive nature of all banks operating at a future date.

Author information: Khaldoun M. Al-Qaisi is an assistant professor of finance in Amman Arab University in Jordan. His address is: P.O. BOX 1825, Amman (11821) Jordan. He may be contacted via E-mail: khaldoun_21@yahoo.com. 


\section{References}

Hall, R., (1988). The Relation Between Price and Marginal Cost in US Industry, Journal of Political Economy 96: 921-947.

Lau, L., (1982). On Identifying the Degree of Competitiveness from Industry Price and Output Data, Economic Letters 10: 93-99.

Murjan, W., and C. Ruza (2002). The Competitive Nature of the Arab Middle Eastern Banking Markets, International Advances in Economic Research 4: 267-274.

Panzar, J., and J. Rosse (1982). Structure, Conduct and Comparative Statistics, Bell Laboratories Economics Discussion Paper.

Panzar, J., and J. Rosse (1987). Testing for 'Monopoly' Equilibrium, Journal of Industrial Economics 35: 443-456.

Prasad, A., and S. Ghosh (2005). Competition in Indian Banking, IMF Working Paper No. 141.

Turk-Ariss, R., (2009). Competitive Behaviour in Middle East and North Africa Banking Sustems, The Quarterly Review of Economics and Finance 49: 693-710.

Yildirim, H., and G. Philippatos (2007). Competition and Contestability in Central and Eastern European Banking Markets, Managerial Finance 33: 195-209.

Yuan, Y., (2006). The State of Competition of the Chinese Banking Industry, Journal of Asian Economics 17: 519-534. 